\title{
チタンのろう付と关の応用 (チタン製熱交換器の製作)
}

\author{
松 康太郎*
}

\section{Brazing of Titanium and Production of All Titanium Heat Exchanger}

\author{
Kotaro Matsu
}

\section{Synopsis}

Titanium and titanium alloys have been successfully used for many applications. On the other hand, joining is understood to be one of the most important processes involved in making products. Many joining processes have been established and employed in industrial fields. Of these processes, brazing in particular is useful for the joining complex or precision parts. In order to do brazing work, it requires not only to have knowledge of brazing technology, but also to be familiar with all properties of brazed materials itself. In this paper, it is explained about titanium and how to braze titanium.

Brazing titanium has been thought unreliable because there were no sufficient brazing filler metals that can successfully resist chloride attack. Prof. T. Onzawa developed titanium based brazing filler metals with low melting point in his prior study and these filler metals showed excellent in joint strength and corrosion resistance. We carefully investigated those filler metals and chose appropriate one for brazing heat exchanger. Then all titanium heat exchanger was made by brazing as one of the examples of titanium brazing work.

\section{1 .はじめに}

金属材料を製品として利用するためには加工技術が必 要不可欠であり，光れが困難な材料では使用分野が制限さ れてしまう：数ある加工技術の中でも接合は重要な位置を 占めており,あるものを形にするには必ずといっていいほ ど接合部分がある.光れには同じ材料同士の組合せの場合 もあれば，異なった材料同士の組合せの場合もあり，兴の 接合方法も樣々である.金属の接合方法で最も代表的なも のとして溶接をあげることが出来る.光の溶接方法の一種 であるろう付は優れた特長を持っているため,多くの製品 の接合に用いられている .

一方で近年, 航空宇宙機器, 化学工業, 自動車, 電子部 品から一般消費財にいたるまで小型化, 軽量化, 高品質化 が進み, 光れに伴いチタンや光の合金, セラミックスなど の利用が急速に増加している .中でもチタンは地款中に豊 富にあり,構造用金属としてはアルミニウム, 鉄 , マグネ シウムについで4 番目に多い金属である ${ }^{1)}$. 光してチタン
は耐食性, 耐熱性に優れ, また比強度が大きいなどの特性 を有するため, 銅, アルミニウムに続く金属材料として重 要な位置を占めてきている .

日本はチタンの生産量, 使用量ともに世界的に有数の国 家であり,世界中で使用されるチタンは大きく分けて日本 とアメリカ, ヨーロッパで3分されるほどである.しかし ながら,チタンの接合方法として溶接は工業的に数多く適 用されているが,乃う付は一部めがね産業などで適用され ている他はあまり利用されていないのか現状である.关れ はチタンの最も優れた特長である耐食性に対応できるろ う材が無かった事とろう付方法が工業的に確立されてい なかったことがあげられる．

弊社では長年培ってきたろう付技術の中からチタンの ろう付技術を応用し,オールチタン製のプレート型熱交換 器 (ろう付タイプでは世界初) を開発した.弚こで本稿で はチタンのろう付と炎れにより製作したチタン製熱交換 器について紹介する. 


\section{2.チタンのろう付}

チタンは非常に優れた性質を持った金属であるが,兴の 特性が逆にろう付にとって障害となり，作業が制限されて いることも事実である.弚のため,チタンをろう付する際 にはチタンの性質を的確に把握し，乥れに最適なろう材と ろう付方法を慎重に選択することが重要である.

\section{1 チタンの性質と特徵}

純チタンの比重は 4.5 で, 鉄の 7.9 とアルミの 2.7 の中 間にあり，弚れは銅やニッケルの約 2 分の 1 , 鋼の約 6 割 という軽さである．また，純チタンの融点は $1,668{ }^{\circ} \mathrm{C} て ゙$ 鉄 の弚れより高い .

純チタンの強度はあまり高くはないが,重量当たりの比 強度はステンレス鋼や普通鋼を上回り,アルミニウムの約 3 倍である.チタン合金では特殊鋼と同等の強さを持ち， $500{ }^{\circ} \mathrm{C}$ 前後の高温でも光の性質はほとんど変化しない．

純チタンは $882{ }^{\circ} \mathrm{C}$ までは a 相の稠密六方構造であり， この温度以上では $\beta$ 相の体心立方構造に同素变態をする． この変態温度は $\beta$ トランザスと呼ばれるが, チタン中の 不純物の量や性質を改善するための合金元素によって影 響を受ける このようにチタンに光の他の元素を添加する ことによって チタン合金になり，乥の元素の種類によっ $\tau a$ 型, $a+\beta$ 型, $\beta$ 型の合金になる.

チタンは酸素 $(O)$ と強い化学親和性を持ち, 安定で強 固な酸化被膜を清浄な表面に急速に形成する .これは不動 態となり，塩や酸化溶液に対して高い耐食性と無機酸への 抵抗を示す.酸素との親和性は温度と共に強くなり,酸化 膜は高温で光の厚さを増す $.650^{\circ} \mathrm{C}$ 以上ではこの酸化抵抗 は急に減少するので, 污染と酸素や室素による脆化を避け るために大気から遮断しなければならない．

\section{2 チタンのろう付で注意する点}

（1）万う材の選定：チタンは耐食性の良い材料であるが， 弚れに対応できるろう材はチタン系の数種類に限られる。 弚の他のろう材の場合は，耐食性を重視しない目的の接合 に限る。

（2）万う付温度 : 純チタンおよび a 型チタン合金は熱処 理なしで使用されるため,基本的にはろう付熱サイクルが 母材の物性に影響しない，しかし，強度の冷間加工を受け ていたり長時間の加熱を行うと，結晶粒の粗大化を受け母 材強度が低下する . 純チタンは光の变態温度 $\left(882^{\circ} \mathrm{C}\right)$ 以 上で長時間の加熱を行うと，脆化や結晶粒の粗大化等の影 響がでる場合がある。

$\beta$ 型チタン合金は熱処理によって高い強度を得ている ので, ろう付温度に注意する必要がある.つまり，溶体化
処理温度以上でろう付を行うと強度は当然低下する．

$\alpha+\beta$ 型チタン合金は熱処理合金なので,万う付温度が 高すぎたり冷却速度が不適切であると脆化したり，結晶粒 が粗大化し母材強度が低下する.従って, 母材の微細組織 を保持するために $\beta$ トランザス以下の温度でろう付をす ることが必要であり，ろう材の融点が問題になる . $\alpha+\beta$ 型チタン合金の代表である Ti-6Al-4V 合金の $\beta$ トランザ ス温度は 955 〜 $995^{\circ} \mathrm{C}$ である。

(3) 万う付雰囲気 : チタンは極めて活性で, 高温において 多くのガス $(\mathrm{C}, \mathrm{N}, \mathrm{O}, \mathrm{H})$ との親和力が強く，これらのガス を吸収すると硬さか増し勒性が低下する.従って大気中の ガスろう付には向いていない.またろう付雾囲気にも制限 があり，一般的にはアルゴンまたは真空雰囲気中でろう付 が行われる.

(4) 化合物の生成: チタンは多くの金属元素と容易に金属 間化合物を生成し，乥のほとんどは硬くて脆い .この硬く て脆い金属間化合物が成長した場合，接合体の強度は著し く低下する.従ってチタンをろう付する際には，万う付界 面 (ろう材と母材の接触面) での合金層 (主に金属間化合 物) の生成を極力抑える必要がある .

\section{3 万う材の種類と光の性質}

ろう材の選択には，接合される母材やろう付温度，使用 環境などを考慮に入れることが大切である.チタン用のろ う材として, 多くの種類のものが研究開発されているが, これを大別すると銀系ろう，アルミ系ろう，チタン系ろう に分けることが出来る. 以下にこれらのろう材について述 べる．

(1) 銀系万う: 純銀をろう材としてチタンのろう付をした 場合，弚の接合界面は金属間化合物の TiAg が生成される が ,この相は勒性があるのでろう付部はほとんど脆化しな い. 従って, 純銀はチタン用のろう材として適している が, 純銀产のものの強度が低い為接合強度が低く，また， 融点が $960{ }^{\circ} \mathrm{C}$ とかなり高いという欠点がある.乥こで純銀 に他の金属を添加して，接合強度の増加やろう材の融点低 下等の改善を図ったろう材を使用するのが普通である．

(2) アルミ系ろう: 純アルミやアルミ合金を弚のままろう 材として使用するが，アルミ母材に光の $10 \%$ 程度の厚み をもつ Al-Si系ろうをクラッドしたブレージングシートも 使用され，後者のほうが高い接合強度を示す．

(3) チタン系ろう : チタン系のろう材は接合強度が他のろ う材に比較して高く耐食性にも優れている.しかしこのろ う材は加工性が悪く，箔にすることが難しいので， $\mathrm{Ti}, \mathrm{Ni}$, $\mathrm{Cu}$ などの䇴をろう組成にあわせて厚みを変えて積層させ たクラッドろうとして使用されている.弚れ以外で最近で 
は,粉末ろうをバインダーと混合させペースト状にして使 用している .これらのろう材の一例を表 1 に示す．

\section{4 チタンのろう付方法}

チタンのろう付方法として，以下の方法が実際に行われ ている.

(1) ガスろう付法:一般にはニッケルメッキ処理をして銀 ろう付をしている .この場合はフラックスを使用する .

(2) 高周波乃う付法: アルゴン又は真空雾囲気中で行う . ま た，ガスろう付と同樣のろう付 (ニッケルメッキ処理を行 い, フラックスを使用) も可能である .チタンは高周波の 乗りがいいので, 高周波を加熱源とすることは有効である （3）雰囲気万う付法: アルゴンガス雰囲気用の連続炉が製 品化され，実用されている.特に時計や装飾品などのろう 付に実用されている。

(4) 真空万う付法 : 最も一般的な方法で, $10^{-2} \mathrm{~Pa}$ 以下の真 空中またはアルゴンのキャリアガス中で実用運転されて いる. 大型の機械部品，熱交換器などに適している。

（5）抵抗ろう付法 : 眼鏡フレームや小型部品にアルゴン
シールをして実用化している．ただし温度制御に問題が 残っている.

\section{3.チタンのろう付応用例 (チタン製熱交換器の製作)}

\section{1 熱交換器の種類}

熱交換器には樣々な種類のものがあり，世の中のいた るところで使用されている．熱交換器の形式を分類する と表 2 に示すようなタイプがある2) .

谷の他に以下のような種類の熱交換器もある.

(1) 二重管熱交換器

(2) 管熱交換器

(3) コンパクト型熱交換器

（4）蓄熱式熱交換器

(5) 全熱交換器

以上のように樣々な種類の熱交換器が世の中に存在し， 弚れらは用途や要求特性を満たす為に樣々な材質で作られ ている．もちろん弚の中にはチタン製の熱交換器もある.

表 1 主なチタン用ろうの種類と炎の組成

\begin{tabular}{|c|c|c|c|c|c|}
\hline 分類 & 種類 $*$ & 規格 & 組成（wt％) & 溶融温度 $\left({ }^{\circ} \mathrm{C}\right)$ & 備考 \\
\hline \multirow{7}{*}{$\mathrm{Ag}$ 系 } & TB-608 & BVAg-8 & $\mathrm{Ag}-28 \mathrm{Cu}$ & 780 & \multirow{4}{*}{ キャリアガス使用 } \\
\hline & TB-608A & BAg-8a & $\mathrm{Ag}-28 \mathrm{Cu}-0.2 \mathrm{Li}$ & $770-775$ & \\
\hline & TB-608B & BVAg-8b & $\mathrm{Ag}-28 \mathrm{Cu}-0.5 \mathrm{Ni}$ & $780-795$ & \\
\hline & TB-608T & & $\mathrm{Ag}-28 \mathrm{Cu}-2 \mathrm{Ti}$ & $780-800$ & \\
\hline & TB-629 & BVAg-29 & $\mathrm{Ag}-24 \mathrm{Cu}-14 \mathrm{In}$ & $620-710$ & \\
\hline & TB- 601 & $\mathrm{BAg}-1$ & $\mathrm{Ag}-15 \mathrm{Cu}-16 \mathrm{Zn}-24 \mathrm{Cd}$ & $605-620$ & 母材にメッキ処理 \\
\hline & TB-607 & $\mathrm{BAg}-7$ & $\mathrm{Ag}-22 \mathrm{Cu}-17 \mathrm{Zn}-5 \mathrm{Sn}$ & $620-650$ & \\
\hline \multirow{2}{*}{ Al系 } & & & $\mathrm{Al}$ & 660 & \\
\hline & TB-504 & BA4047 & $\mathrm{Al}-12 \mathrm{Si}$ & 580 & \\
\hline \multirow{5}{*}{$\mathrm{Ti}$ 系 } & TB-1510 & & Ti-37.5Zr-15Cu-10Ni & 842 & \\
\hline & TB-2020 & & Ti-20Zr-20Cu-20Ni & $820-880$ & \\
\hline & TB-2500 & & Ti-37.5Zr-25Cu & 825 & \\
\hline & TB-5000 & & Ti-25Zr-50Cu & $810-860$ & \\
\hline & & & $\mathrm{Ti}-15 \mathrm{Cu}-15 \mathrm{Ni}$ & $910-960$ & クラッドろう (Ticuni) \\
\hline
\end{tabular}

${ }^{*}$ 種類は(株)東京ブレイズの製品番号

表 2 主な熱交換器の種類と光の用途例

\begin{tabular}{|c|c|c|c|}
\hline 熱交換器形式 & 流体 A & 流体 B & 用途例 \\
\hline \multirow{5}{*}{ シェル・アンド・チューブ } & 空気 & 燃焼ガス & 再生器、排熱回収 \\
\hline & 水 & 冷媒 & 冷凍機、バイナリ一サイクル \\
\hline & 相変化有機媒体 & 相変化有機媒体 & 化学プラント \\
\hline & 海水 & 蒸発する LNG & LNG 気化器 \\
\hline & 蒸発する水 & 高温ヘリウム & 高温ガス炉蒸気発生器 \\
\hline \multirow{2}{*}{ プレート型 } & 空気 & オイル & オイルクーラー \\
\hline & 水 & 水 & 水クーラー \\
\hline コンパクト型 & 空気 & 空気 & エアクーラー \\
\hline フィン付管 & 有機液体 & 空気 & 化学プラントクーラー \\
\hline フィン・アンド・チューブ & 相変化する冷媒 & 空気 & 空調機 \\
\hline コルゲートフィン & 水 & 空気 & 自動車用ラジエーター \\
\hline
\end{tabular}


チタンの特性を最大に生かせる用途としては, 耐食性の要 求される (特に海水を利用する) 分野への応用が主であ る.しかしながらチタンの熱交換器はほとんどが溶接構造 で出来ているので, シェル・アンド・チューブ型など限ら れた種類の熱交換器しか実際には生産されていないのが 現状である。

プレート型熱交換器はコンパクトで熱交換性能にも優 れるなどの理由から，幅広い分野で大量に使用されてい る このタイプの熱交換器は大別するとガスケットタイプ とろう付タイプがあり,チタン製ではガスケットタイプの プレート型熱交換器が生産・販売されている.しかし前述 のように,ろう付タイプが存在しなかったのは,十分に耐 食性のあるろう材が無かった為と，光のろう付方法か確立 されていなかった為である。

プレート型熱交換器には,プレート自体にフィン形状を 付けて張り合わせるプレートフィンタイプと,プレート間 にインナーフィンを挟み込むインナーフィンタイプとが ある.弊社の熱交換器には，接合面積が多く製品の強度を 確保でき，また流水抵抗の少ないプレートフィンタイプを 採用した 、インナーフィンには特別形状のスタックド・V フィンを採用し,熱交換率の向上を図った.図 1 に内部構 造と流体通路の模式図を示す。

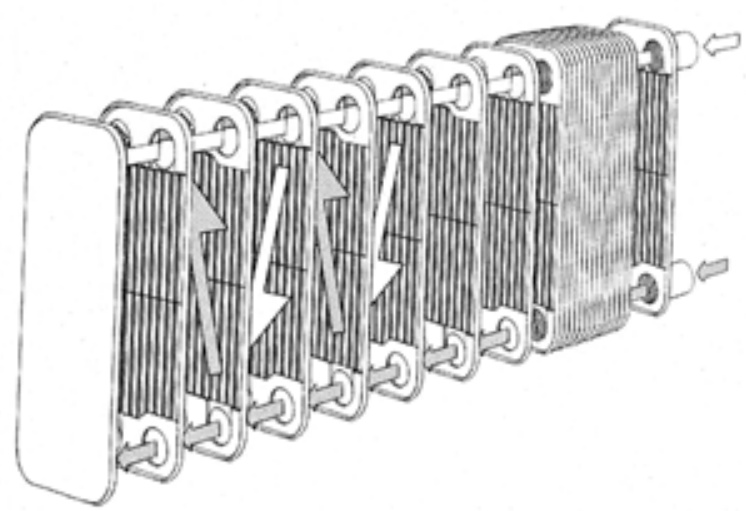

\section{2 万う材とろう付方法の選択}

ろう付タイプのチタン製熱交換器には,もちろんろう材 自体に耐食性が求められる，乥こで表 1 の中からは自然と チタン系のろう材が選択されることになる.また，耐食性 で特に問題になるのはろう材に含まれる $\mathrm{Cu}$ の量であるの で, チタン系ろうの中から $\mathrm{TB}-1510$ と TB-2020 が候補に なった この2種類のろう材の比較試験結果を以下に示す． 3.2 .1 耐食性試験

表 3 に浸漬による耐食性試験の結果を示す .この試験は 試験片を腐食溶液に浸漬して経過時間後の腐食減量を測 定することにより耐食性を評価したものである.比較のた めに母材となる純チタンと一般的な耐食材料である SUS304 も同時に試験を行っている．表は 720 時間後の試 験結果を示したものである.○は外観で全く腐食が確認さ れず腐食減量も全く無かった状態で, $\triangle は$ 外観で微量の腐 食もしくは微量の腐食減量が確認された状態を示してい る.×は著しく腐食された状態である。

TB-1510 はどの腐食液に対しても全く腐食されていない ことが分かる. TB-2020 は次亜塩素酸ナトリウムに対して 微量腐食されている．母材となる純チタンは全く問題ない が, SUS304 は塩酸と次亜塩素酸ナトリウムに著しく腐食 され アアンモニアに対しても微量の腐食か確認されている.

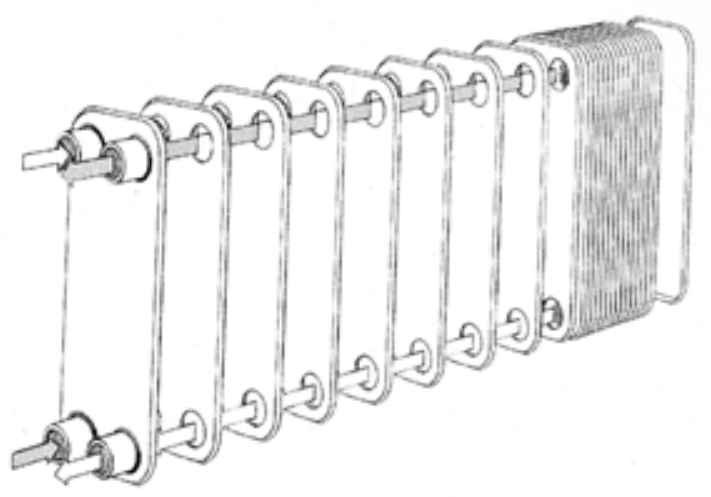

图 1 インナーフィン (スタックド・Vフィン) タイプ熱交換器の構造

表 3 浸漬による耐食性試験結果

\begin{tabular}{|c|c|c|c|c|}
\hline 腐食薬品 & TB-1510 & TB-2020 & 純チタン & SUS304 \\
\hline $\begin{array}{c}\text { 塩酸 } \\
\mathrm{HCl}=5 \%\end{array}$ & $\bigcirc$ & $\bigcirc$ & $\bigcirc$ & $\times$ \\
\hline $\begin{array}{c}\text { 次亜塩素酸ナトリウム } \\
\mathrm{NaClO} \text { (有効塩素量 =2\%) }\end{array}$ & $\bigcirc$ & $\triangle$ & $\bigcirc$ & $\times$ \\
\hline $\begin{array}{c}\text { 海水 (人工海水) } \\
\mathrm{NaCl}=3.5 \%\end{array}$ & O & $\bigcirc$ & $\bigcirc$ & $\bigcirc$ \\
\hline $\begin{array}{c}\text { アンモニア水 } \\
\mathrm{NH}_{3}=10 \%\end{array}$ & $\bigcirc$ & $\bigcirc$ & $\bigcirc$ & $\triangle$ \\
\hline
\end{tabular}




\subsection{2 接合界面組織}

图 2 と図 3 は代表的な接合部断面組織である.図は共 に TB-1510を用いて純チタンをろう付した試験片の組織 であるが，TB-2020 の断面組織も基本的には同じである 図 2 と図 3 の違いはろう付時間で,時間が短い場合はろう 材層が界面に残り，また EDXによる分析結果より，ろう 材中にあった $\mathrm{Cu}$ が濃化されていることが判る.これは， 耐食性に対しても不利になる，一方，乃う付時間が長いと ろう材の母材中への溶融や拡散が進み, 液相拡散接合とな りろう材層は消失する。

\section{2 .3 強度試験}

図 4 にTB-1510 と TB-2020の $880^{\circ} \mathrm{C}, 10 \mathrm{~min}$ と $60 \mathrm{~min} て ゙$ ろう付した試験片のせん断試験による強度測定結果を示 す. 各ろう材ともに $60 \mathrm{~min}$ では 300MP a 以上の強度を得 られており良好なせん断強度を示している.破断形態はい ずれも母材を引きずる形で起きていたので，母材強度と同 等の強度が得られていると考えられる これによりろう材 層の消失させることにより高強度の接合体が得られるこ とが分かる.

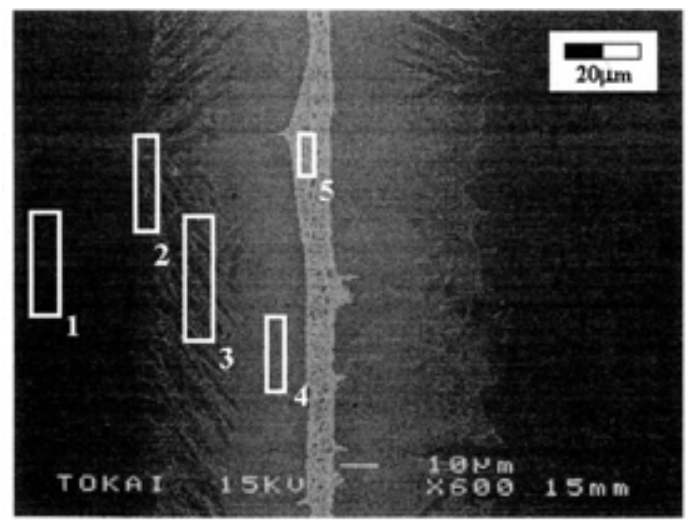

\begin{tabular}{||c|c|c|c|c||}
\hline \multirow{2}{*}{ Position } & \multicolumn{4}{|c|}{ Chemical Composition (mass\%) } \\
\cline { 2 - 5 } & $\mathrm{Ti}$ & $\mathrm{Zr}$ & $\mathrm{Cu}$ & $\mathrm{Ni}$ \\
\hline 1 & 100 & 0 & 0 & 0 \\
\hline 2 & 85 & 7 & 5 & 3 \\
\hline 3 & 78 & 13 & 6 & 3 \\
\hline 4 & 68 & 21 & 8 & 3 \\
\hline 5 & 35 & 33 & 22 & 10 \\
\hline
\end{tabular}

図 2 TB-1510による代表的な接合部断面組織と EDXによる元素分析結果 $\left(860{ }^{\circ} \mathrm{C}, 10 \mathrm{~min}\right)$

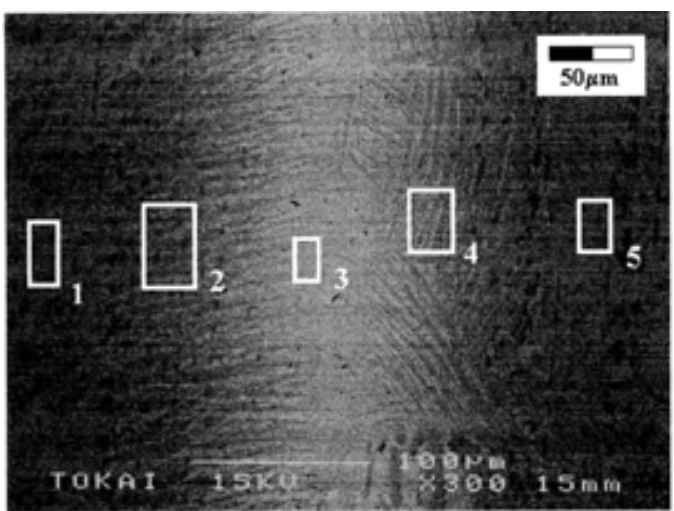

\begin{tabular}{||c|c|c|c|c||}
\hline \multirow{2}{*}{ Position } & \multicolumn{5}{|c|}{ Chemical Composition (mass\%) } \\
\cline { 2 - 5 } & $\mathrm{Ti}$ & $\mathrm{Zr}$ & $\mathrm{Cu}$ & $\mathrm{Ni}$ \\
\hline 1 & 97 & 0 & 1 & 2 \\
\hline 2 & 80 & 12 & 5 & 3 \\
\hline 3 & 70 & 20 & 8 & 2 \\
\hline 4 & 83 & 10 & 4 & 3 \\
\hline 5 & 98 & 0 & 1 & 1 \\
\hline
\end{tabular}

図 3 TB-1510による代表的な接合部断面組織と EDXによる元素分析結果 $\left(860{ }^{\circ} \mathrm{C}, 60 \mathrm{~min}\right.$ )
一方 $10 \min$ では強度が著しく低下している.せん断試験 後の断面組織を観察したところ破断位置は全てろう材層中 で発生していたことから，短時間のろう付時間やクリアラ

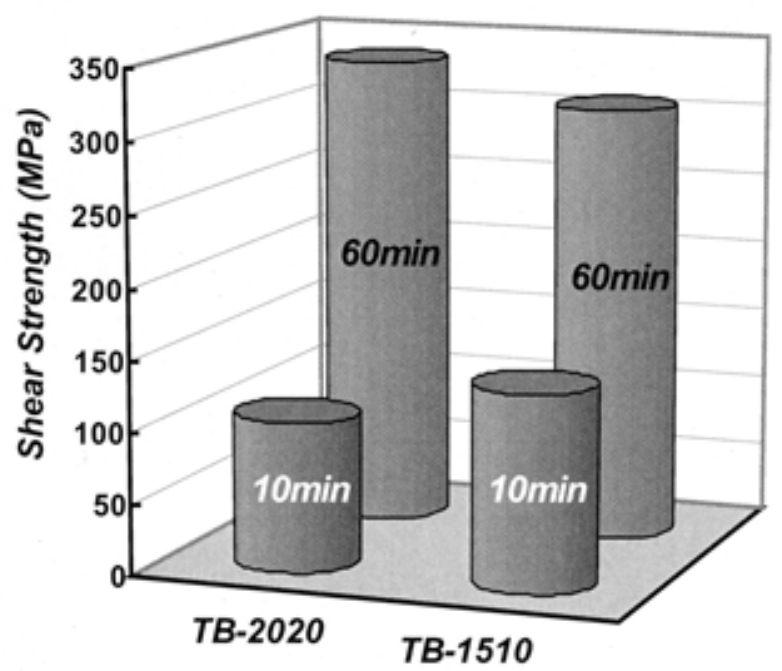

図 4 TB-1510 と TB-2020 の $860{ }^{\circ} \mathrm{C}, 10 \mathrm{~min}$ と $60 \mathrm{~min}$ でろう付し た試験片のせん断試験結果 
ンスの広い継手はろう材層を残す状態になるので,ろう付 条件としては良くないと言える。

以上の耐食性試験，接合界面組織観察および強度試験の 結果により，TB-1510は耐食性や接合強度ともに優れ，万 う材の融点も純チタンの変態温度より約 $40{ }^{\circ} \mathrm{C}$ 低いことか ら，ろう付タイプのチタン製熱交換器に最も適していると 言える。

\section{2 .4 万う付方法}

チタン製熱交換器ろう付方法としては, 真空ろう付法が 最も適している.実際のろう付には半連続式真空炉を用い て真空と Ar キャリアガスを併用した雾囲気中で行った この真空炉は複数のチャンバーを持ち, 間欠駆動により ワークの移動を行うので熱交換器の量産には最も適して いる。

\section{3 チタン製熱交換器の性能}

図5にチタンろう材を用いてろう付されたプレート型熱 交換器の外観写真を示す . これらは TB-HE-Ti-5 型と TBHE-Ti-10 型である . この他にプレートのサイズを大きく した TB-HEL-Ti-10 型と TB-HEL-Ti-20 型か現在までに作 製され，弚れらの仕樣と性能を表 4 に示す．

この熱交換器を他の熱交換器と比較すると以下のよう になる

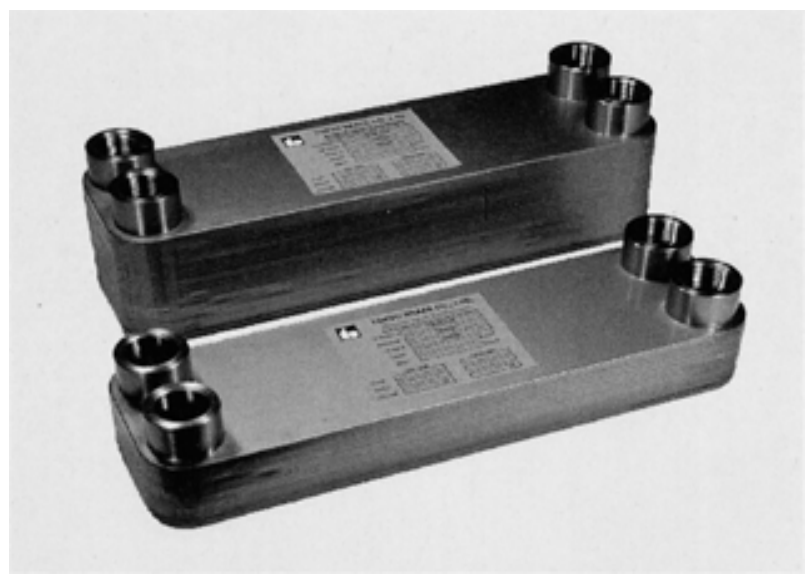

図 5 チタン製ろう付タイププレート型熱交換器の外観
(1) シェル・アンド・チューブ型の熱交換器との比較

・直径 $100 \mathrm{~mm}$ x 長さ $500 \mathrm{~mm}$ のシェル・アンド・チューブ 型熱交換器では, 伝熱面積は約 $0.05 \mathrm{~m}^{2}$ で熱交換性能は $3,000 \mathrm{Kcal} / \mathrm{hr}$ になる

・外観上がほぼ同じプレート型熱交換器（TB-HE-Ti-5 型) は, 伝熱面積が約 $0.3 \mathrm{~m}^{2}$ でシェル・アンド・チューブ型 熱交換器の 6 倍となり, 性能も 5 〜 倍となる

・プレート型熱交換器 (TB-HE-Ti-5 型) は, 直径 $170 \mathrm{~mm} \mathrm{x}$ 長さ $1,000 \mathrm{~mm}$ のシェル・アンド・チューブ型熱交換器と 該当する

(2) 自動車用ラジェーター熱交換器との比較

•乗用車用は $1,500 \sim 2,000 \mathrm{cc}$ クラスで $15,000 \sim 20,000 \mathrm{Kcal} / \mathrm{hr}$ (TB-HE-Ti-5 型と同等)

・トラック 4 トン車クラスで 40,000Kcal/hr（TB-HE-Ti-10 型と同等)

・トラック 10 トン車クラスで $100,000 \mathrm{Kcal} / \mathrm{hr}$

3.4 プレート型チタン製熱交換器の用途 今後, ろう付タイプのプレート型チタン製熱交換器は, 以下の用途が考えられる

(1) 化学プラント

(2) 医療機器

(3) 食品工業

(4) 活魚輸送用いけすおよび活魚用水槽

(5) 船舶・海洋機器

(6) プールなど

(7) 弚の他

\section{4 .おわりに}

弊社はこのたびチタンのろう付の一例として ,プレート 型熱交換器の製作を行い製品化に成功することができた . これは社内の技術向上努力はもちろんであるが,関係各者 の甚大なる御協力を頂いたからに他ありません. 特にろう 材を開発された東京工業大学の恩澤忠男教授，各種試験お よび分析にご尽力を頂いた東海大学の有賀正教授，宮澤靖

表 4 プレート型チタン製熱交換器の主仕樣

\begin{tabular}{|c|c|c|c|c|}
\hline 品番 & TB-HE-Ti-5 & TB-HE-Ti-10 & TB-HEL-Ti-10 & TB-HEL-Ti-20 \\
\hline 熱交換量 Kcal/hr & 20,000 & 40,000 & 130,000 & 260,000 \\
\hline 両流体入口温度差 ${ }^{\circ} \mathrm{C}$ & 50 & 50 & 50 & 50 \\
\hline 形式 & \multicolumn{4}{|c|}{ プレート型インナーフィン式 (スタックド・Vフィン) } \\
\hline 回路 (高温側 / 低温側) & 5 回路 /6 回路 & 10 回路 /11 回路 & 10 回路/11 回路 & 20 回路 /21 回路 \\
\hline 放熱面積 $\mathrm{m}^{2}$ & 0.260 & 0.521 & 1.667 & 3.334 \\
\hline 流量 $\mathrm{L} / \mathrm{min}$ & 20 & 40 & 130 & 260 \\
\hline 寸法 $(\mathrm{L} \times \mathrm{W} \times \mathrm{H}) \mathrm{mm}$ & $311 \times 90 \times 67$ & $311 \times 90 \times 105$ & $580 \times 150 \times 105$ & $580 \times 150 \times 182$ \\
\hline 本体重量 $\mathrm{Kg}$ & 2.16 & 3.82 & 11.45 & 20.25 \\
\hline
\end{tabular}


幸助教授には感謝の念が尽きません この場をお借りして 御礼申し上げます.昨今の厳しい状況の中弊社はさらに研 究を進め,チタンのろう付による他のアプリケーションに も挑戦し，世界で勝負できる製品を生み出すことが今後の 生き残りに最も必要であると考えます。

(文 献)

1)正野ら:溶接技術, 35(1987),1,136-141

2)日本機会学会:伝熱工学資料 III 機器編(2001),[丸善] 